\title{
Penggunaan Model Pembelajaran Contextual Teaching And Learning (CTL) Untuk Meningkatkan Hasil Belajar Peserta Didik Pada Materi PPKN Keberagaman Sosial, Budaya, dan Ekonomi Masyarakat
}

\section{Desi Ernawati}

SD Negeri Sengon 03

desiernawati42@gmail.com

\section{Article History}

received 3/12/2020

\begin{abstract}
The problem of the value of student learning outcomes in PPKn lessons on the subject of social, cultural, and economic diversity of the community which is still low and the average value has not reached the KKM, is the basis for this research. Based on the results of observations made by researchers, one of the obstacles faced in Civics learning is about an ineffective learning model. To overcome this, researchers use a CTL (Contextual Teaching and Learning) learning approach to improve Civics learning outcomes material Diversity social, cultural, and economic community in SD Negeri Sengon 03, Tanjung District, Brebes Regency. This type of research uses classroom action research with two cycles. The results of the first cycle reflection, the achievement of the average score only reached 70 , learning completeness only reached $57 \%$. Only 19 students completed from 33 students. While the results of the reflection in the second cycle, the average value increased, namely 78 or $89 \%$. So it can be concluded that by applying the CTL learning model, it can improve the learning outcomes of Civics on the subject of social, cultural and economic diversity of the community.
\end{abstract}

Keywords: CTL learning model, learning outcomes PPKn

\begin{abstract}
Abstrak
Permasalahan nilai hasil belajar peserta didik pada pelajaran PPKn materi Keberagaman sosial,budaya,dan ekonomi masyarakat yang masih rendah dan nilai rata-rata yang belum mencapai KKM,menjadi dasar dalam penelitian ini. Berdasarkan hasil observasi yang dilakukan peneliti,salah satu hambatan yang dihadapi dalam pembelajaran PPKn adalah mengenai model pembelajaran yang kurang efektif.Untuk mengatasinya,peneliti menggunakan pendekatan pembelajaran CTL ( Contextual Teaching and Learning ) untuk meningkatkan hasil belajar PPKn materi Keberagaman sosial,budaya,dan ekonomi masyarakat di SD Negeri Sengon 03 Kecamatan Tanjung Kabupaten Brebes. Jenis penelitian ini menggunakan penelitian tindakan kelas dengan dua siklus. Hasil refleksi siklus pertama,ketercapaian rata-rata nilai hanya mencapai 70,ketuntasan belajar hanya mencapai $57 \%$. Hanya 19 siswa yang tuntas dari 33 siswa. Sedangkan hasil refleksi pada siklus kedua,mengalami peningkatan nilai rata-rata yaitu 78 atau $89 \%$.Sehingga dapat disimpulkan bahwa dengan menerapkan model pembelajaran CTL dapat meningkatkan hasil pembelajaran PPKn materi Keberagaman sosial,budaya dan ekonomi masyarakat.
\end{abstract}

Kata kunci: model pembelajaran CTL, hasil belajar PPKn

Social, Humanities, and Education Studies (SHEs): Conference Series https://jurnal.uns.ac.id/shes

p-ISSN 2620-9284

e-ISSN 2620-9292 


\section{PENDAHULUAN}

Pada pembukaan Undang - undang Dasar 1945 alinea 4 tercantum salah satu tujuan nasional Indonesia yaitu Mencerdaskan Kehidupan Bangsa.Untuk mencapai tujuan tersebut, Pemerintah Indonesia melalui Kementerian Pendidikan dan Kebudayaan berupaya mengadakan perbaikan dan pembaharuan sistem Pendidikan di Indonesia ( Putra dkk,2014 ). Melalui pendidikan bangsa ini membebaskan masyarakat dari kebodohan dan keterpurukan serta dapat mengembangkan sumber daya manusia yang percaya diri untuk bersanding dan bersaing dengan bangsa lain. Peningkatan mutu Pendidikan merupakan sasaran pembangunan di bidang Pendidikan nasional dan merupakan bagian integral dari upaya peningkatan kualitas manusia Indonesia secara menyeluruh.

Amir ( 2009:2) menyatakan "Dunia Pendidikan,khususnya di sekolah dasar (SD),merupakan pangkal dari suatu proses Pendidikan formal yang berkelanjutan. Untuk itu, Pendidikan di SD memerlukan adanya peningkatan kualitas untuk merespon perkembangan ilmu pengetahuan dan teknologi." Peningkatan kualitas salah satunya dilakukan dengan meningkatkan mutu pembelajaran. Peningkatan mutu pembelajaran dapat dicapai jika guru telah melakukan pembelajaran yang inovatif dengan menempatkan peserta didik sebagai pusat pembelajaran dan mereka dapat belajar bermakna.

Dalam upaya pencapaian tujuan Pendidikan,guru perlu melaksanakan proses pembelajaran dengan baik.Sehinggaa dapat meningkatkan hasil belajar peserta didik. Menurut Hendrawati( 2013), hasil belajar adalah penilaian yang diperoleh peserta didik setelah melakukan kegiatan pembelajaran dan berkenaan dengan penguasaan materi yang telah diterima selama pembelajaran berlangsung. Salah satu faktor yang mempengaruhi hasil belajar peserta didik adalah model pembelajaran yang digunakan oleh guru.Apabila guru menggunakan metode pembelajaran yang tepat dan inovatif,maka peserta didik akan termotivasi untuk belajar dan proses belajar menjadi menyenangkan. Peserta didik semakin semangat dalam belajar ketika guru dapat memberikan pembelajaran menggunakan metode yang mudah diterima ( Syaerozi,Eko.S.dan Sutarno,2015).

Pembelajaran yang efektif dan menyenangkan dapat diterapkan diberbagai mata pelajaran,salah satunya adalah PPKn (Setiana,2012). Menurut Lestari (2014),Pendidikan Kewarganegaraan dapat didefinisikan sebagai proses pengembangan dan perbaikan diri bagi setiap warga negara dengan usaha sadar dan terencana melalui pengajaran dan pelatihan sehingga terjadi peningkatan potensi diri dalam hal pengetahuan,sikap,dan keterampilan.Tujuan Pendidikan kewarganegaraan adalah mewujudkan warga negara sadar bela negara berlandaskan pemahaman politik kebangsaan, dan kepekaan mengembangkan jati diri dan moral bangsa dalam perikehidupan bangsa.

Dalam pembelajaran PPKn masih jarang ditemukan model pembelajaran yang inovatif,guru seringkali mengajar hanya menggunakan metode ceramah. Sehingga menyebabkan peserta didik kurang tertarik untuk mendengarkan penjelasan guru. Hal ini tentu akan mempengaruhi hasil belajar peserta didik terutama pada mata pelajaran PPKN.

Fakta yang terjadi pada kelas VI SD Negeri Sengon 03,nilai hasil belajar peserta didik pada mata pelajaran PPKn materi Keberagaman sosial budaya,dan ekonomi masyarakat masih rendah, nilai rata-rata hanya mencapai 58 . Nilai rata-rata tersebut belum mencapai kriteria ketuntasan minimal yang ditetapkan yaitu 67 , dan ketuntasan belajar peserta didik hanya 14 peserta didik yang tuntas atau $43 \%$,sedangkan 19 peserta didik (57\%) lainnya masih dibawah KKM. Masalah rendahnya nilai prestasi pada mata pelajaran PPKn materi kebergaman sosial,budaya, dan ekonomi masyarakat disebabkan oleh (1). Keterlibatan peserta didik dalam proses pembelajaran masih kurang, ( 2 ) proses pembelajaran satu arah berpusat pada guru ( 
3 ) strategi pembelajaran kurang menarik minat peserta didik. ( 4 ) penggunaan alat peraga kurang maksimal. Sehingga perlu dilakukan perbaikan dalam pembelajaran PPKn.

Setelah dilakukan beberapa kajian tentang model pembelajaran yang ada,maka model yang dgunakan yaitu metode Contextual Teaching and Learning ( CTL ) .Menurut Nurhadi dalam Sugiyanto (2007) CTL adalah konsep belajar yang mendorong guru untuk menghubungkan antara materi yang diajarkan dan situasi dunia nyata peserta didik. Menurut Jonhson dalam Sugianto (2007) CTL adalah sebuah proses pendidikan yang bertujuan untuk menolong peserta didik melihat makna didalam materi akademik yang mereka pelajari dengan cara menghubungkan subyek-subyek akademik dengan konteks dalam kehidupan keseharian mereka. Menurut Susanto ( 2016:236 ) karakteristik model CTL yaitu :

Keadaan yang mempengaruhi kehidupan peserta didik dan pembelajarannya; 2) dengan menggunakan waktu/kekinian,yaitu masa yang lalu ,sekarang,dan yang akan dating; 3) lawan dari textbook centered; 4) lingkungan budaya,sosial,pribadi,ekonomi, dan politik;5) belajar tidak hanya menggunakan ruang kelas,bisa dilakukan di dalam kehidupan keluarga,masyarakat,bangsa dan negara;6)mengaitkan isi pelajaran dengan dunia nyata dan memotivasi peserta didik membuat hubungan antara pengetahuan dengan penerapannya dalam kehidupan mereka;7)membekali peserta didik dengan penerapnnya dalam kehidupan mereka;8)membekali peserta didik dengan pengetahuan yang fleksibel dapat diterapkan dari suatu permasalahan ke permasalahan lain,dari satu konteks ke konteks lain.

Selain itu,pembelajaran kontekstual mendorong peserta didik untuk menemukan hubungan antara materi yang dipelajarinya dengan situasi dunia nyata.Bukan hanya mengharapkan peserta didik dapat memahami materi yang dipelajarinya,akan tetapi bagaimana materi pelajaran itu dapat mewarnai perilakunya dalam kehidupan seharihari (Desyandri,2012) Sintaks (langkah-langkah) atau fase-fase model pembelajaran kontekstual (CTL) menurut Sa'ud (2014, hlm. 173-174) adalah sebagai berikut: 1) Invitasi (Mengemukakan pengetahuan awal),2) Eksplorasi ( Menyelidiki dan menemukan konsep, melalui pengumpulan data), 3) Penjelasan dan solusi (Memberikan penjelasan dan solusi berdasarkan hasil observasi ), 4) Pengambilan data ( Membuat keputusan berdasarkan pengetahuan,informasi dan keterampilan ).

Menurut Sitiatava ( 2013,hlm.259) penerapan pendekatan CTL memiliki beberapa kelebihan sebagai berikut : 1) Pembelajaran menjadi lebih bermakna dan riil (nyata);2) Pembelajaran lebih produktif dan mampu menumbuhkan penguatan konsep kepada peserta didik karena CTL menganut aliran kontruktivisme;3) Kontekstual adalah model pembelajaran yang menekankan pada aktivitas peserta didik secara penuh baik fisik maupun mental;4) Kelas dalam pembelajaran kontekstual bukan sebagai tempat untuk memperoleh informasi,tetapi sebagai tempat untuk menguji data hasil temuan di lapangan;5) Materi pelajaran dapat ditemukan sendiri oleh peserta didik bukan hasil pemberian guru;6)Penerapan pembelajaran kontekstual bisa menciptakan suasana pembelajaran yang bermakna. Sedangkan kekurangan CTL menurut Sitiatava (2013,hlm.259) adalah sebagai berikut : 1) Diperlukan waktu yang cukup lama saat proses pembelajaran kontekstual berlangsung;2) Jika guru tidak dapat mengendalikan kelas,maka bisa menciptakan situasi kelas yang kurang kondusif; 3)Guru lebih intensif dalam membimbing,karena dalam CTL guru tidak lagi berperan sebagai pusat informasi; dan 4) Guru memberikan kesempatan peserta didik untuk menemukan atau menerapkan sendiri ide-ide serta mengajak peserta didik menggunakan strateginya sendiri dalam belajar.

Berdasarkan latar belakang yang telah dijelaskan,peneliti melakukan penelitian dengan judul " Penggunaan Model Pembelajaran Contextual Teaching and Learning (CTL) Untuk Meningkatkan Hasil Belajar Peserta Didik Pada Materi PPKn 
Keberagaman Sosial,Budaya,dan Ekonomi Masyarakat di SD Negeri Sengon 03 Kabupaten Brebes Tahun Pelajaran 2019/2020 “.

\section{METODE}

Pelaksanaan Penelitian dimulai tanggal 01 Agustus 2020 sampai 31 Desember 2020 di SD Negeri Sengon 03 Kecamatan Tanjung,Kabupaten Brebes. Subjek penelitian adalah peserta didik kelas VI sebanyak 33 orang.

Jenis penelitian ini adalah Penelitian Tindakan Kelas (PTK) atau Classroom Action Research.Penelitian ini dilaksanakan dalam 2 siklus.Pada setiap siklus terdiri dari perencanaan, pelaksanaan,observasi/evaluasi,serta refleksi.

Sumber data peserta didik diperoleh dari hasil observasi yang diperoleh secara sistematik selama pelaksanaan siklus pertama sampai siklus kedua,hasil evaluasi,dan hasil wawancara pengamat (observer) . Sumber data guru didapatkan dari lembar observasi aktivitas guru oleh observer.sedangkan sumber data dokumen diperoleh dari data awal hasil tes, hasil pengamatan, catatan lapangan selama proses pembelajaran dan hasil foto.

Teknik pengumpulan data pada penelitian ini adalah metode observasi, metode tes dan dokumentasi. Pengumpulan data kuantitatif adalah data yang diperoleh dari hasil belajar peserta didik. Data kualitatif diambil dari lembar pengamatan aktivitas peserta didik, keterampilan guru, wawancara serta catatan lapangan.

Teknik analisis data yang digunakan adalah : Data berupa hasil belajar PPKn dianalisis menggunakan teknik analisis deskriptif dengan menentukan mean atau ratarata.Adapun penyajian data kuantitatif dipaparkan dalam bentuk persentase,Data kualitatif berupa hasil data hasil observasi aktifitas peserta didik dan aktifitas guru dalam pembelajaran CTL , serta hasil catatan lapangan dan angket dianalisis menggunakan deskriptif kualitatif.

\section{Hasil Penelitian Siklus 1}

\section{HASIL DAN PEMBAHASAN}

Pada pelaksanaan pembelajaran siklus 1 terdapat 3 tahap yaitu tahap awal,tahap inti, dan tahap penutup. Pada tahap awal dilakukan beberapa kegiatan yaitu guru mengkondisikan suasana belajar yang menyenangkan,mengaitkan materi sebelumnya dengan materi yang akan dipelajari, menyampaikan manfaat materi pembelajaran yang akan dipelajari dalam kehidupan sehari-hari, menyampaikan garis besar cakupan materi,menyampaikan kompetensi yang akan dicapai, menyampaikan garis besar kegiatan yang akan dilakukan ( kegiatan kerja kelompok,untuk bermain peran sebagai tamu atau tuan rumah ), dan menyampaikan lingkup dan tehnik penilaian.

Dalam kegiatan inti,guru menjelaskan materi Keberagaman Sosial,Budaya, dan ekonomi masyarakat,tanya jawab tentang arti keberagaman sosial,budaya,dan ekonomi masyarakat, contoh-contoh keberagaman yang ada di masyarakat,sikapsikap yang perlu dikembangkan dalam menghadapi kebergaman yang ada di masyarakat. Selanjutnya guru membagi peserta didik menjadi 4 kelompok,dan membagi serta menjelaskan tugas / lembar kerja kelompok, memfasilitasi peserta didik membuat laporan eksplorasi yang dilakukan baik lisan maupun tertulis (Individu maupun kelompok ), memfasilitasi peserta didik untuk menyajikan hasil kerja individual maupun kelompok, peserta didik melaporkan hasil pemikirannya secara lisan,membuat generalisasi definisi yang telah dibuat oleh semua peserta didik. Guru bertanya jawab tentang hal-hal yang belum diketahui peserta didik serta guru bersama peserta didik bertanya jawab meluruskan kesalahan pemahaman, memberikan penguatan, dan penyimpulan.

Pada tahap penutup, kegiatan yang dilaksanakan oleh guru yaitu bertanya jawab tentang materi yang telah dipelajari (untuk mengetahui hasil ketercapaian materi), 
peserta didik melakukan perenungan dengan menjawab pertanyaan yang terdapat pada buku siswa ( ada 3 hal yang mereka pelajari di hari ini,bagian yang sudah mereka pahami dengan baik, bagian yang belum dipahami, apa manfaat yang mereka peroleh, serta apa yang mereka ingin ketahui lebih lanjut), melakukan penilaian hasil belajar, dan mengajak semua peserta didik berdoa menurut keyakinannya masingmasing.

Pada kondisi awal, nilai rata-rata kelas pada pembelajaran sehari-hari hanya mencapai 58, ini belum mencapai kriteria ketuntasan minimal yang ditentukan,yaitu 67 , dan ketuntasan belajar peserta didik hanya 14 orang yang tuntas atau $43 \%$, sedangkan 19 orang ( $57 \%$ ) lainnya masih di bawah KKM. Dari data tersebut disajikan dalam bentuk table 1 .

Tabel 1. Hasil Analisis Penilaian Kondisi Awal

\begin{tabular}{ccccc}
\hline \multirow{2}{*}{ Jumlah siswa } & \multicolumn{4}{c}{ Siswa yang memperoleh Nilai } \\
\cline { 2 - 5 } & $\leq 67$ & $\geq 67$ & Tuntas & Belum Tuntas \\
\hline 33 & 19 & 14 & 14 & 19 \\
Persentase & $57 \%$ & $43 \%$ & $43 \%$ & $57 \%$ \\
\hline
\end{tabular}

Setelah dilakukan penelitian,diperoleh hasil refleksi pembelajaran pertemuan kedua pada siklus I yaitu nilai rata-rata kelas menjadi 70 . Hal ini menunjukkan adanya peningkatan dari kondisi awal,ketuntasan belajar hanya $57 \%$ atau 19 peserta didik yang tuntas dari 33 peserta didik kelas VI SD Negeri Sengon 03, meskipun nilai ratarata sudah mencapai KKM, tetapi secara klasikal ketuntasan belajar masih menunjukkan persentase di bawah $75 \%$, oleh karena itu peneliti bersama observer menganggap bahwa harus ada perbaikan pembelajaran pada siklus berikutnya. Temuan-temuan pada pelaksanaan perbaikan pembelajaran pada siklus 2 . Berikut rincian hasil penilaian pada siklus I.

a. Hasil Penilaian Kerja Kelompok

Hasil penilaian 5 kelompok belajar antara lain : Kelompok Yupiter nilai rata-rata 75 kategori Cukup baik,Venus 72,5 Cukup Baik,Mars 82,5 Kategori Sudah Baik,Saturnus 80 Sudah Baik, Neptunus Sudah Baik.

b. Hasil Penilaian Tes formatif

Nilai rata-rata kelas adalah 70 ini sudah menunjukkan peningkatan dari kondisi awal, ketuntasan belajar $57 \%$ atau 19 peserta didik yang tuntas dari 33 peserta didik, dan yang belum tuntas 14 peserta didik atau $43 \%$. Data tersebut disajikan dalam tabel 2.

Tabel 2. Hasil Analisis Tes Formatif Siklus 1

\begin{tabular}{ccccc}
\hline \multirow{2}{*}{ Jumlah siswa } & \multicolumn{4}{c}{ Siswa yang memperoleh Nilai } \\
\cline { 2 - 5 } & $\leq 67$ & $\geq 67$ & Tuntas & Belum Tuntas \\
\hline 33 & 14 & 19 & 19 & 14 \\
Persentase & $43 \%$ & $57 \%$ & $57 \%$ & $43 \%$ \\
\hline
\end{tabular}

\section{Hasil Penelitian Siklus 2}

Pelaksanaan perbaikan pembelajaran siklus 2 mengacu pada RPP yang telah disusun setelah ada perbaikan kekurangan dalam pelaksanaan pembelajaran siklus 1. Hasil refleksi siklus 2 diperoleh nilai rata-rata kelas adalah 78. Selisih 11 dari KKM yang ditentukan yaitu 67.Peserta didik yang tuntas 29 atau $89 \%$ dari 33 peserta didik.

a. Hasil Penilaian Kerja Kelompok

Hasil penilaian 4 kelompok belajar antara lain : kelompok Yupiter nilai rata-rata 80 kategori Sudah Baik,Venus 82,5 Sudah Baik,Mars 83,74 Kategori Sudah Baik,Saturnus 87,5 Sangat Baik,Neptunus sudah Baik. 
b. Hasil Penilaian Tes Formatif

Nilai rata-rata kelas adalah 78 ini sudah selisih, $11 \mathrm{KKM}$ yang ditentukan yaitu 67.Peserta didik yang tuntas 29 atau $89 \%$ dari 33 peserta didik,sedangkan yang belum tuntas 4 peserta didik atau $11 \%$.Data tersebut disajikan dalam table 3 .

Tabel 3. Hasil Analisis Tes Formatif Siklus 2

\begin{tabular}{ccccc}
\hline \multirow{2}{*}{ Jumlah siswa } & \multicolumn{4}{c}{ Siswa yang memperoleh Nilai } \\
\cline { 2 - 5 } & $\leq 67$ & $\geq 67$ & Tuntas & Belum Tuntas \\
\hline 33 & 4 & 29 & 29 & 4 \\
Persentase & $11 \%$ & $89 \%$ & $89 \%$ & $11 \%$ \\
\hline
\end{tabular}

Berdasarkan hasil analisis penilaian mulai dari kondisi awal sampai kondisi akhir di siklus 2, terlihat ada peningkatan yang signifikan baik pada penilaian hasil kerja kelompok, penilaian tes formatif,yaitu : pada kondisi awal nilai rata-rata 58, menjadi 70 di siklus 1 , dan 78 di siklus 2, sedangkan peningkatan jumlah peserta didik yang tuntas di kondisi awal sebanyak 14 peserta didik menjadi 19 peserta didik di siklus 1 dan 29 peserta didik di siklus 2,adapun persentase peningkatan ketuntasan belajar secara klasikal antara lain pada kondisi awal 43\% menjadi $57 \%$ di siklus 1, dan $89 \%$ di siklus 2. Dari data tersebut disajikan pada table 4.

Tabel 4. Hasil Analisis Penilaian Mata Pelajaran PPKn

\begin{tabular}{llccccc}
\hline \multirow{2}{*}{ No } & \multirow{2}{*}{ Uraian } & Jumlah & \multicolumn{2}{c}{ Siswa yang } & siswas & \multicolumn{2}{c}{ Siswa Belum Tuntas } \\
\cline { 4 - 7 } & & Frekuensi & $\%$ & Frekuensi & $\%$ \\
\hline 1. & Kondisi Awal & 33 & 14 & $43 \%$ & 19 & $57 \%$ \\
2. & Siklus I & 33 & 19 & $57 \%$ & 14 & $43 \%$ \\
3. & Siklus II & 33 & 29 & $89 \%$ & 4 & $11 \%$ \\
\hline
\end{tabular}

Peningkatan Nilai rata-rata tes formatif mulai dari kondisi awal sampai siklus 2 disajikan dalam table 5.

Tabel 5. Peningkatan Nilai Rata-rata tes formatif

\begin{tabular}{clcc}
\hline No & & Uraian & Nilai Rata-Rata \\
\hline 1 & Kondisi Awal & & 58 \\
2 & Siklus I & 70 \\
3 & Siklus II & & 78 \\
\hline
\end{tabular}
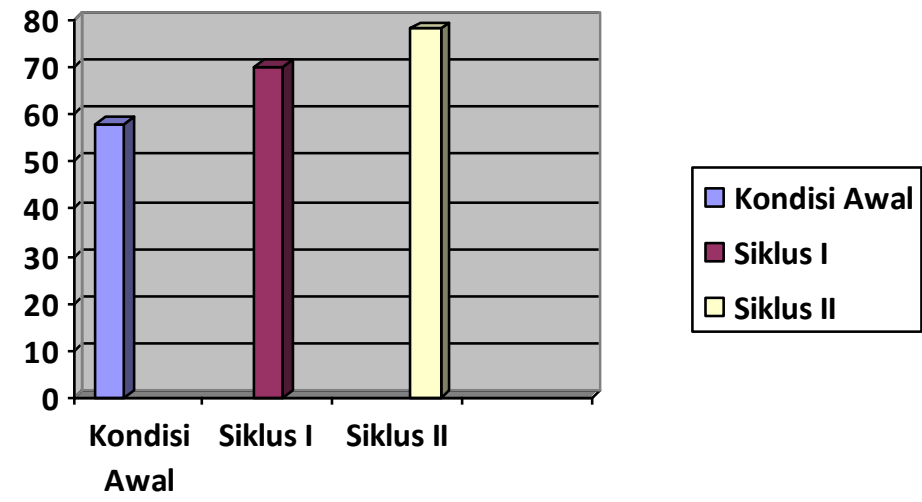

Gambar 1. Grafik Peningkatan Nilai Rata - Rata Tes Formatif 


\section{SIMPULAN}

Dari hasil penelitian,dapat disimpulkan bahwa dengan menerapkan model pembelajaran Contextual Teaching and Learning ( CTL ) dapat meningkatkan hasil belajar peserta didik mata pelajaran PPKn dengan materi Keberagaman Sosial,Budaya, dan Ekonomi Masyarakat di SD Negeri Sengon 03 Kecamatan Tanjung,Kabupaten Brebes. Hal ini dapat terlihat dari kondisi awal dengan nilai ratarata 58, setelah dilakukan perbaikan pembelajaran dengan CTL mengalami peningkatan nilai rata-rata sebesar 70 pada siklus pertama dan 78 atau $89 \%$ peserta didik dinyatakan tuntas pada siklus kedua.

\section{DAFTAR PUSTAKA}

Amir,M.Taufiq.2009. Inovasi Pendidikan Melalui Problem Base Learning. Jakarta : Kencana Prenada Media Group.

Desyandri.(2012). The Usage of Contextual Teaching and Learning (CTL) Approach to improve the process and learning outcome of Singing to the Student Class III Elementary School YPKK of Padang State University.Pedagogi:Jurnal IImu Pendidikan,12(1),36-52.Retrieved http://pedagogi.ppj.unp.ac.id/index.php/pedagogi/article/view/231

Hendarwati,Endang.2013.Pengaruh Pemanfaatan Lingkungan sebagai Sumber Belajar Melalui Metode Inkuiri terhadap Hasil Belajar Siswa SDN 1 Sribit Delanggu pada Pelajaran IPS. Jurnal Pedagogia Vo.2(1):59-70

Lestari,Nurtia.2014.Upaya Meningkatkan kedisplinan dan Prestasi Belajar PKn Materi Contoh Peraturan Perundang-undangan di Kelas V Melalui Value Clarification Technique Tipe Perisai Kepribadian di SD La Irsyad I Purwokerto.Jurnal IImiah Pendidikan Dasar Vo. 1 (1):74-86

Putra,I Dewa Made Arta,Ign.I Wyn Suwarta, dan Desak Pt.Parmiti.2014. Pengaruh Model Pembelajaran Value Clarification Technique (VCT) terhadap Hasil Belajar PKn Siswa Kelas V. Jurnal Mimbar PGSD Universitas Pendidikan Ganesha Volume 2 (1).

Sa'ud,U.S.(2014).Inovasi Pendidikan. Bandung:Alfabeta.

Setiana,Gustin Indra.2012. Penerapan Model Pembelajaran Value Clarification Tehnique Permainan Untuk Meningkatkan Hasil Belajar PKn pada siswa kelas II SD Negeri Kemandungan 3 Kota Tegal.Skripsi:Jurusan Pendidikan Guru Sekolah Dasar Universitas Negeri Semarang.

Sitiatava Rizema Putra.(2013).Desain Belajar Mengajar Kreatif Berbasis Sains.Yogyakarta:Diva Press.hlm.259

Sugianto.2007.Modul Pendidikan dan Latihan Profesi Guru (PLPG):Model-model Pembelajaran Inovatif.Surakarta:Panitia Sertifikasi Guru Rayon 13 Surakarta.

Susanto,Ahmad.2016.Teori Belajar dan Pembelajaran di Sekolah Dasar.Jakarta:Kencana.

Syaerozi,Eko Supraptono, dan Sutarno.2015. Penerapan Metode Pembelajaran Drill Berbantuan Multimedia Interaktif dalam Materi Microsoft Excel 2007. Jurnal Penelitian Tindakan Kelas (Didaktikum) Vol. 16(4) : 75-84. https://i.rpp.com/index.php/didaktikum/article/download/310/311. 